\title{
Мовностильові особливості драматургії Петера Турріні
}

\author{
Л. М. Ткаченко, Л. О. Береза
}

\author{
Черкаський державний технологічний університет, м. Черкаси, Україна \\ Corresponding author. E-mail: tkatschenko@ukr.net
}

Paper received 29.01.20; Accepted for publication 16.02.20.

\section{https://doi.org/10.31174/SEND-Ph2020-218VIII66-13}

Аннотація. Розглянуто й проаналізовано деякі аспекти творчості П. Турріні. Схарактеризовано мовні, мовленнєві та мовностильові особливості відтворення психології представників середніх і нижчих прошарків суспільства. Розкрито проблематику ранніх та пізніх п’єс драматурга. 3'ясовано, що за допомогою мовних аспектів Петер Турріні виробив свій самобутній стиль, що характеризується, насамперед, шоковим ефектом, якого драматург досягає своєрідним написанням п'єс: нехтування орфографічними нормами, використання вульгаризмів, жаргонізмів та «фекальних» висловів, насичення простих, коротких речень героїв імперативом, що підсилило грубість висловлювань.

Ключові слова: діалект, драматургія, мовленнєвий аспект, мовностильові особливості, n'єса.

Вступ. Мовні та стилістичні особливості творів іноземних письменників та поетів занурюють в атмосферу життя героїв творів та є своєрідним засобом презентації іхнього національного менталітету. До таких видатних літераторів, чиї твори розкриваються поособливому при читанні рідною мовою письменника і в перекладі українською, є Петер Турріні. Вивчаючи мовні особливості ідіостилю П. Турріні, важливо зосередити увагу на аналізі ранніх та пізніх його п'єс. Для адекватної інтерпретації художнього тексту необхідно чітко знати особливості мови героїв, оскільки мова $є$ своєрідним відображенням покоління та ключем до розкриття особистості. Австрійський драматург Петер Турріні (II пол. XX ст.) є яскравим представником покоління «молодих» авторів. Своїми творами П. Турріні змусив по-новому поглянути на традиційне театральне мистецтво та його героїв. Деякими аспектами своєї творчості П. Турріні спирався на традиції віденської народної п'єси. Беззаперечний успіх його п'єс значною мірою пояснюється умінням автора різноаспектно зображувати соціальнопсихологічну атмосферу навколо персонажів, психологію представників середніх і нижчих верств суспільства. Петер Турріні - передусім, психолог людської душі - завоював читача і глядача своїми авангардистськими нововведеннями, філософською заглибленістю, сатиричною спрямованістю п’єс та ескалацією природних почуттів.

Аналіз останніх досліджень і публікацій. У зарубіжному літературознавстві творчості П. Турріні присвячено праці Г. Ауста, У. Бірбаумера, П. Гаїда, Ю. Гайна, Й. Гольцнера, Д. Давіау, Г. Земанна, Є. Корманн, Ю. Ланди, Б. Мюллера, В. Сєдєльніка, М. Тьотенберга, Б. Фішера, Г. Фогельзанга, Т. Шмідта. Здебільшого це лише окремі рецензії та оглядові статті, які мають ознайомлювальний характер. Поза увагою дослідників залишився зокрема такий важливий аспект у доробку автора, як мовностильові особливості його п'єс.

Мета статті полягає в дослідженні мовностилістичних особливостей драматургії П. Турріні. Особливої уваги приділено аналізові самобутнього стилю автора, що досягається шляхом використання певних мовних засобів.

Актуальність теми зумовлена суспільною значущістю літературного доробку П. Турріні - одного 3 найпомітніших представників австрійської народної п’єси, а також відсутністю у вітчизняному літературознавстві спеціального дослідження, присвяченого вивченню композиційної побудови, стильових особливостей драматичних творів цього автора.

Методи дослідження. 3-поміж провідних методів, використаних у дослідженні, важливу роль відіграє герменевтичний метод, що дав змогу проаналізувати досліджувані тексти драм та окреслити їхню основну проблематику й поетику. Застосування конкретноісторичного методу дозволило вивчати основні періоди творчого розвитку драматурга. Метод порівняльного аналізу сприяв виявленню спільних та відмінних рис у творах різних періодів творчості письменника в процесі зіставлення їх 3 класичною драматургічною спадщиною.

Виклад основного матеріалу. Кожна п'єса П. Турріні викликає інтерес не лише своєю проблематикою, а й мовностильовим оформленням, яке також шокує читача/глядача. Це стосується не лише діалекту, який автор використовує з метою дійти до найпростішого глядача та загострити увагу на проблемах певного соціального прошарку, але, насамперед, брутальної лексики, вульгаризмів, якими пересипані монологи та діалоги персонажів. Драматург не прикрашає мовлення героїв складними науковими термінами, він не вигадує нової мови. Навпаки, синтаксична побудова речення проста, герої п'єс часто використовують певні мовні кліше, штампи, що вказує на їхню обмеженість та залежність від суспільства.

Завдяки вмілому користуванню мовою, драматург глибоко розкриває внутрішній світ своїх героїв. Так, у п’єсі «Полювання на щурів» він досягає подвійного ефекту, дуже точно передаючи фонетичне звучання героїв із вадами, яким воно $є$ в конкретній ситуації. При цьому драматург не зважає на орфографічні норми, поділяючи погляди представників «Віденської групи», які у своїй творчості часто вдавалися до іконографічних інновацій. Уживання діалектної, брутальної лексики, вульгаризмів, лайливих слів вражало глядача, письменник упевнений у правдивості таких висловлювань, адже вони належали його персонажам, які жили в такому середовищі, де подібні вислови були нормою:

Він: ...ти свиня!

Вона: Падлюка! 


\section{Він: Паскуда!}

Вона: Гівнюк!!!

Він: Ідіотка!!!

Вона: Блядюга!!! [238, S. 62].

На противагу такій лексиці письменник використовує слова 3 рекламних щитів, що сприймаються як щось чужорідне в такому оточенні. У тексті вони написані великими літерами: - ПАПЕРОВІ НОСОВІ ХУСТИНКИ, М'ЯКІ, НЕМОВ ШОВК, СТІЙКІ ДО ТРІЩИН, АНТИБАКТЕРІАЛЬНІ, ОПРОМІНЕНІ. Автор наголошує, що саме така брехлива реклама і справжньою непристойністю.

Одна 3 характерних рис мовлення героїв П. Турріні - короткі, емоційні речення, сповнені діалектизмами та «фекальними» висловами: «...усе навкруги - відходи, екскременти, лайно... Як тільки хтось розкриває рота - смердить, відчуття, немовби тонеш у багнюці» [7, с. 25]. Лексикон автора - нескладний, він не вживає пишномовної лексики, що б свідчила про надвисокий рівень освіти мовця. Драматург звертається до різних форм висловлювання, які вже самі по собі $\epsilon$ грубими та вульгарними. Як бачимо, мовлення героїв насичене імперативом, що підтверджує вияв грубості стосовно співрозмовника: «Послухай-но, підійди, не церемонься, уперед...!» [7, с. 17].

У п’єсі «Забій свиней» мова стає основним засобом комунікації для вираження думки автора, своєю художньою творчістю П. Турріні засвідчує вагу мови в суспільстві, оскільки вона є важливим засобом самореалізації. У цьому творі драматург показує так званого безмовного героя, у конкретному випадку П. Турріні немов би відмовляється від вербального спілкування як головного елемента побудови діалогу в драматургічних творах. Мовлення героя - це своєрідна сатира на повсякденну мову, адже в ній наявний комічний елемент - «хрюкання».

Під час мовного дресирування з боку сільської верхівки, якого зазнає головний герой Валентин, можна почути звинувачення у «спотворенні мови» [3]. Ці «освічені» люди, виправдовуючи свою жорстокість, використовують прислів'я, цитати з Біблії. Садистські знущання, припікання свічкою підошов, виливання помиїв у обличчя супроводжуються такими коментарями: «кожен отримує по заслугах» [8, с. 118], «кожен чинить так, як він спроможний» [8, с. 106], «а я вмиваю руки» [8, с. 107]. Уміле використання вульгаризмів i жаргонізмів допомагає авторові поглиблено охарактеризувати кожну дійову особу. На цьому ефекті й базується концепція П. Турріні, що прагне вивести глядача зі стану байдужості. Змальовуючи образи сільської знаті, драматург розкриває специфіку правлячих кіл в Австрії: «Звичайно, не ми, австрійці, вигадали владу, ми просто робимо іiі дещо розважальною. Отже, нас правомірно називають щиросердним маленьким народом» [8, с. 83].

Виправдовуючи свої дії, знать використовуєрекомендації, уживаючи неозначено-особовий займенник «man». Такі настанови вони часто вкладають у вуста слуги Зеппа: «Честь тому, хто заслуговує честі, як-то кажуть», «Знать - це не ті, хто прийшов сюди від імені пана, як-то говорять» [8, с. 107]. Зепп сам не настільки лукавий, оскільки він $є$ жертвою мовних маніпуляцій.
Чим зумовлений такий мовний терор, стає зрозумілим у заключній сцені, коли сільська знать перед убивством Валентина пояснює позицію влади, висловлюючись професійним жаргоном:

Священик: Нехай земля буде пухом, як часто я повинен усе ж таки це казати [8, с. 118].

Адвокат: 3 юридичного погляду, можна було б говорити про субгуманну форму вияву, коли взагалі до уваги беруть усе в кримінально-правовому плані [8, c. 117].

Вчитель: Слова можуть мати важкі наслідки. Наші класики вже справді все сказали [8, с. 118].

Упродовж дії п'єси селянин і селянка благають головного героя, аби той заговорив, у заключній сцені всі присутні наполягають на тому, що слід позбутися аутсайдера. Діалог виконує важливу функцію в системі внутрішньої комунікації, зокрема тоді, коли починають поширювати плітки по селу. У зовнішній системі комунікацій мова, усупереч дії, часто має експресивну функцію. Так звана «притча» П. Турріні звернена певною мірою безпосередньо до публіки, аби глядачі сприймали Валентина в спілкуванні та діях по-іншому, ніж ті селяни, що діють на сцені. Іноді драматург робить це поетично, вдало використовуючи діалектні форми:

Селянин: Щодо мого сумління, то це, безперечно, найбільше стосується мене самого, це моє. Не задивляйся на чужі речі, ти - шпигун!

Франи: Мати не знає того, що знає кожен.

Селянин: А що знає кожен?

Франи: Те, що є сумлінням, про що кожен повинен знати, коли розплющує очі.

Селянин: А що є сумлінням?

Франич: Це вже відомо.

Селянка: Звичайно, це неправильно.

Селянин: (бурмоче) Знаєте, та що ви там знаєте? [8, c. 97].

У п’єсах «Полювання на щурів» та «Забій свиней» драматург вживає локальні діалекти, які розкривають і характеризують місце реальної комунікативної ситуації, тобто таке мовлення адресоване лише певному соціальному прошарку населення. П. Турріні послуговується діалектами ще й для того, щоб зосередити увагу на гострих проблемах, які існують у суспільному середовищі.

Згодом автор переписав свою першу п'єсу літературною мовою, оскільки більшості читачам було важко сприймати діалектні форми. Драматург відмовився від використання діалекту, щоб показати різні рівні думок - простого та привілейованого населення: «Це є спробою зобразити поведінку людини, яка залежить від умов та можливостей життя» [10, с. 206]. У подальших творах автор уживає лише окремі діалектні слова або репліки, щоб акцентувати самобутність тієї чи тієї особи. Його герої вживають водночас вульгарну мову, проте це не лихий намір, а лише самозахист від жорстокої реальності. Їхнє мовлення - це ознака відчуження індивідуума, уживання різних кліше, рекламних висловлювань робить людей залежними. Використання розмовної лексики виконує роз'яснювальну функцію, оскільки така мова слугує засобом вираження тих образ, що люди зазнають у суспільстві. Лексика героїв П. Турріні тісно пов'язана 
3 соціальним середовищем, саме тому в мовленні аутсайдерів та маргіналів найбільше лайливих слів.

Мова у творах драматурга слугує тим дієвим інструментом, який допомагає поєднати комічне та трагічне. У драмі «Мій Нестрой» П. Турріні збагачує мовлення головного героя виразними та дотепними жартами, що, на нашу думку, увиразнює сатиричний погляд на буденну комунікацію та вдавану народність розважальної драматургії. Письменник імітує афоризми реального Нестроя, приписуючи своєму герою дещо видозмінені вислови історичної особи: «Постійно, коли я бачу щось пов'язане зі смертю, то я навіть відчуваю, як росте трава, де я ляжу трупом» [5, с. 17], «Успіх несе в собі те, що раніше здавалося чимось більшим, ніж виявилося насправді» [5, с. 50],«Земля - це небесне тіло, де люди ведуть пекельне життя» [5, с. 60].

Характеризуючи п’єсу «Йозеф і Марія», зазначимо, що художні особливості цієї драми помітно відрізняються від попередніх п’єс письменника, оскільки за допомогою мови автор демонструє солідарність зі своїми героями і водночас із глядацькою публікою, відмовляється від агресивних елементів. Мовлення дійових осіб плавно переходить від монологів до діалогів, П. Турріні насичує мовлення головного персонажа висловами, характерними для службовця.Драматург використовує повсякденну розмовну мову, уживаючи, однак, лише невелику кількість діалектних слів. Головні герої висловлюються зрозумілою всім лексикою не через повагу до іноземного глядача, а тому, що вони якось втратили свою рідну мову. Йозеф та Марія спілкуються між собою експресивно й пафосно, кожен із них хоче представити себе 3 найкращого боку, вдаючись при цьому до мови жестів. Ще ефективнішою представлена мова в системі зовнішньої комунікації.

Основна частина твору - це подвійний монолог, оскільки кожен із героїв розповідає про своє минуле й теперішнє життя, не слухаючи при цьому одне одного. Використання такої монологічної форми лише посилює експресивну функцію, розкриваючи самотність двох людей, які не звикли спілкуватися зі своїм оточенням, вести діалог, оскільки для них уже стало звичним використання монологічної форми, ромова самих з собою. Таке монологічне мовлення допомагає читачам довідатися більше про життя головних персонажів. П. Турріні більш експліцитно, ніж в інших творах, показує, чому його герої є саме такими людьми. Через їхні монологи з'ясовані різні причини, які призвели до появи таких холодних стосунків між людьми в їхньому оточенні. У випадку з Йозефом це насамперед тягар його політичного минулого, а для Марії - нечуйність близьких людей, особисті образи. П. Турріні змальовує двох людей, які розмовляють, так би мовити, різними голосами, але саме завдяки такому мовному спілкуванню вони стають ближчими одне до одного. Характерні репліки Йозефа і Марії, якими вони намагаються висловити свої почуття та бажання:

Марія: ...Я така, яка є...

Йозеф: Перепрошую, «правда» має справді набагато менше переваг [6, с. 19].
У «Йозефі і Марії» драматург використовує просту, зрозумілу читачу/глядачу лексику, яка увиразнює простоту реальної ситуації та дії персонажів. Митець відмовляється від діалекту, який міг би бути доречним, 3 огляду на соціальний стан головних героїв. Автор вкладає в їхні вуста такі вислови, які добре ілюструють реалістичний характер контексту ситуаціï. Такий вибір мовних засобів дає змогу водночас наголосити на щирості й відкритості двох літніх людей - жертв повоєнного австрійського суспільства. У виборі літературної мови помітна зрілість автора, який, набуваючи досвіду, зумів досягти рівноваги в жанрі драматургії.

П'єси П. Турріні слід аналізувати в контексті акцентування уваги на проблемі мови в суспільстві, що іiі порушив і Петер Гандке у своєму творі «Облаювання публіки». Це свідчить про винахідливість П. Турріні, його вміння диференціювати мовлення своїх персонажів. Так, Фауст у драмі «Фауст III. Дивне продовження» («Faust III. Eine merkwürdige Fortsetzung») уживає лексику, що характерна для представників ICO (Міжнародна організація технічних норм та стандартів). У цьому ж творі в окремих сценах він використовує слова, які надають фразам поетичного звучання, наприклад: «Відень - місто, де вирує бурхливе життя». «Німецькими мініатюрами» можна вважати вірш письменника «Пісня Німеччини» («Deutschlandlied»), де розвінчується сутність фашизму та колаж цитат «Привіт тобі» («Heit Dir»), джерелами яких стали висловлювання Гітлера, позапарламентської опозиції ФРН, міщанської преси. В епілозі П. Турріні зазначає: «Такі фрази в цих п’єсах висловлювали лише деякі люди. Вони знову застрягли в окремих головах». У телефонній розмові, що відбулася між юнаком та дівчиною в п’єсі «Ніщо, ніщо» («Zero, zero»), тісно переплітаються фрази святотатської літанії, рекламних закликів, розмов у барі. Набір мовного інструментарію 3 ілюстрованих журналів, порнографічної літератури та політичних промов можна побачити й у романі П. Турріні «Події в ротовій порожнині» («Erlebnisse in der Mundhöhle»). Власне форма розмови, викладена в маленькому листі, без будь-яких орфографічних знаків, породжує додаткові негативні асоціації. Хоч драматург не дотримується при цьому принципу художньої умовності, усе ж такі мовні засоби діють на читача досить ефективно.

Слід звернути увагу й на те, що автор уживає у своїх п'єсах слова, які згодом зникають із мовного вжитку. Як стверджував письменник, «мова створює свідомість, а звуження мовлення веде до обмеженої свідомості» [1, с. 195]. Для прикладу взяти хоча б слово «робітничий клас», вжите в п’єсі «Зайві». Людей виганяють із роботи, ніхто не цікавиться їхніми турботами, вони залишаються наодинці зі своїми начальними проблемами. Отже, поступово зникає власне робітничий клас, а не лише його назва.

У своїх перших п’єсах «Полювання на щурів» та «Забій свиней» П. Турріні використовує діалект, насичений вульгаризмами та непристойними словами, для більшого наближення до глядачів. Драматург не прагне прикрасити мову, а використовує іiі в такому вигляді, як нею розмовляють у побуті пересічні громадяни. Це дає йому змогу відтворити мовну картину 
однієї чи іншої провінційної частини Австрії, мовлення героїв слугує засобом маніпулювання, порятунку від жорстокості й визначає індивідуальний стиль. Ненормативна лексика спонукає персонажів замислитися над своїм існуванням, що є головною метою автора. Відразу від суспільних відносин, що шокує глядача, письменник викриває за допомогою змістового наповнення та форми вираження: «Грубій лексиці та уяві, яка передається словами, що мають вразити, дійняти до живого, відповідає влучна, «дошкульна» автентичність діалекту на фонетичному та морфологічному рівні» [2].

Розвиваючись, митець практично відмовляється від діалекту, збагачує мовлення персонажів афоризмами та дотепними жартами, що додає його творчості сатиричного відтінку. Проста, зрозуміла пересічній людині лексика допомагає П. Турріні точно передати тогочасну ситуацію в суспільстві.

Дуже важливу роль відіграє мова й у драмі «Громадяни», однак головною темою тут, як і в попередніх творах, залишається нездатність говорити: «Громадяни тримають перед нами дзеркало, у якому ми можемо впізнати заніміле покоління» [10, с. 129]. Драматург розкриває беззмістовність висловлювань своїх персонажів, що характеризує культурний рівень людини. Для австрійського драматурга вже не достатньо «зірвати маску з обличчя», щоб показати справжню сутність людини, адже мова й реальна дійсність не збігаються. Герої в «Громадянах» послуговуються штучною мовою, переповненою термінами, що зумовлює ті чи ті зміни в поведінці дійових осіб.

Драматург наголошує на тому, що мова дуже змінюється від покоління до покоління, вона бідніє, зникає іiі колорит. Слушною вважаємо думку Пауля Блахи, директора Бургтеатру у Відні, щодо мовних аспектів драми: «Це - п’єса про мову, мовне відчуження, функціонування мови. Мова - це не лише вираження свого «Я», але й замкнення в собі, це функціональне варварство», як сказав одного разу «старий» у виставі [4].

У п’єсах «Смерть та диявол», «Альпійське сяйво», «Грільпарцер у порномагазині» та «Битва під Віднем» П. Турріні часто використовує вульгаризми, що дає змогу ще більше вирізняти блюзнірство. У мовленні Руді зі «Смерті і чорта» упродовж усієї п’єси відчутний якийсь хворобливий дух його думок, помітна девальвація людських цінностей. У розповідях цього персонажа багато егоїзму й пихатості, свої переконання він вважає непогрішними: «Якщо хтось хоче кимось стати, то потрібно відійти геть. Гітлер також відійшов. Як Ви думаєте, наскільки я рішучий у цьому сенсі?» [9, с. 14].У цій П'єсі П. Турріні використовує віденський діалект у передостанній сцені, коли на вокзалі лунає голос із мікрофона, у такий спосіб автор маркує місце, де відбувається дія.

Мові ранніх творів автора властива певна дратівливість, навіть грубість. Якщо раніше драматург використовував «слова-фекалії», то в його останніх п’єсах уже немає такої злості, у них звучить надія на можливе покращення стану справ. У творах пізнього періоду знайомимося 3 персонажами, які розмовляють уже іншою мовою, звичайно, це ще не свідчить про покращення їхньої моралі, просто реалії буття тут інші. П. Турріні показує героїв у їхньому прагненні виявити свою ідентичність, тобто намагається вирвати їх iз лещат суспільних маніпуляцій.

Дослідники часто звертають увагу на таку проблему, як втрата людиною мовних функцій у творах абсурдистів, що виражено у відвертій критиці мови. Слово для них - не більше, ніж набір знаків, від перестановки яких нічого не змінюється. Відчуження мови від людини трактують як ознаку відчуження людини від своєї сутності; автоматизація мови означає, що людина збайдужіла й перетворилася на механічну ляльку, проте не пафосом викриття та звинувачення людей-ляльок на мовному рівні керуються європейські абсурдисти, зокрема й Петер Турріні. За словами німецького філософа Теодора Адорно, «п'єси абсурдні не тому, що в них зовсім немає сенсу, - бо тоді вони втратили б своє значення, - а тому, що вони ставлять сенс під сумнів і оповідають його історію» [12].

Підсумовуючи сказане, зазначимо, що власне за допомогою мовних аспектів Петер Турріні виробив свій самобутній стиль, що характеризується в першу чергу шоковим ефектом, якого драматург досягає своєрідним написанням п’єс: нехтування орфографічними нормами, використання вульгаризмів, жаргонізмів та «фекальних» висловів, насичення простих, коротких речень героїв імперативом, що підсилило грубість висловлювань.

Мова, якою розмовляють персонажі драм, характеризує не лише стан мовленнєвої комунікації, а й мовну ситуацію в Австрії. Мова творів драматурга завжди зрозуміла та доступна: зазвичай, це прості речення без термінології та вузьких професіоналізмів. Особливість лексики, яку використовує драматург, дає йому впевненість у тому, що його слухатимуть, оскільки вона притягуватиме увагу, мов магніт.

\section{ЛІТЕРАТУРА}

1. Amann, K. Peter Turrini - Schriftsteller, Kämpfer, Künstler, Narr und Bürger. Residenz Verlag, 2007. 230 S.

2. Betten, A. Sprachrealismus im deutschen Drama der 70-er Jahre. Heidelberg, 1985. S. 308.

3. Polaczek Dietmar. Die Sau, die nicht reden will//Kärner Tageszeitung, 19. Januar 1972.

4. Turrini Peter. Die Bürger. Turrini Lesebuch zwei: Stücke, Film, Gedichte, Reaktionen etc./ausgewählt und bearbeitet von Ulf Birbauer. Wien; Zürich: Europaverlag, 1983. 409 S.

5. Turrini Peter. Die Verhaftung des Johann Nepomuk Nestroy (eine Novelle). München: Literaturverlag GmbH, 1998. 76 S.

6. Turrini Peter. Josef und Maria//Turrini Lesebuch zwei: Stücke, Film, Gedichte, Reaktionen etc./ausgewählt und bearbeitet von U. Birbauer. Wien; Zürich, 1983. S. 4-49.

7. Turrini Peter. Rattenjagd/Turrini Lesebuch: Stücke, Pamphlete, Filme, Reaktionen etc./ausgewählt und bearbeitet von U. Birbaumer. Wien; Zürich, 1989. 415 S.

8. Turrini Peter. Sauschlachten//Turrini Lesebuch: Stücke, Pamphlete, Filme, Reaktionen etc./ausgewählt und bearbeitet von U. Birbaumer. Wien; Zürich: Europaverlag, 1989. 415 S.

9. TurriniPeter. Tod und Teufel, eine Kolportage, Theater. Frankfurt am Main: Luchterhand Literaturverlag, 1990. 95 S. 
10. Turrini Peter. Turrini Lesebuch zwei: Stücke, Film, Gedichte, Reaktionen etc./ausgewählt und bearbeitet von
U. Birbauer. Wien; Zürich, 1983.S. 6-8, 76, 127-129, 206, 402-408.

11. Ряс Ж. Поступ сучасних ідей. К.: Основи, 1998. С. 582.

\section{REFERENCES}

1. Amann, K. Peter Turrini - writer, fighter, artist, fool and citizen [Peter Turrini - Schriftsteller, Kämpfer, Künstler, Narr und Bürger]. Residenz Verlag, 2007. 230 p.

2. Betten, A. Sprachrealismus in the German drama of the 70s. [Sprachrealismus im deutschen Drama der 70-er Jahre].Heidelberg, 1985. p. 308.

3. Polaczek Dietmar. The sow that doesn't want to talk [Die Sau, die nicht redden will]// Kärner daily newspaper, January 19, 1972.

4. Turrini Peter. The citizens. Turrini reading book two: plays, film, poems, reactions etc./selected and edited by Ulf Birbauer [Die Bürger. Turrini Lesebuch zwei: Stücke, Film, Gedichte, Reaktionen etc./ausgewählt und bearbeitet von Ulf Birbauer]. Vienna; Zurich: Europaverlag, 1983. 409 p.

5. Turrini Peter. The arrest of Johann Nepomuk Nestroy (a novella) [Die Verhaftung des Johann Nepomuk Nestroy (eine Novelle)]. Munich: Literaturverlag $\mathrm{GmbH}, 1998.76 \mathrm{p}$.

6. Turrini Peter. Josef and Maria [Josef und Maria]//Turrini Reading book two: pieces, film, poems, reactions

etc./selected and edited by U. Birbauer. Vienna; Zurich, 1983. pp. 4-49.

7. Turrini Peter. Rathunting [Rattenjagd]//Turrini reading book: plays, pamphlets, films, reactions etc./selected and edited by U. Birbaumer. Vienna; Zurich, 1989. 415 p.

8. Turrini Peter. Pig battle [Sauschlachten]//Turrini reading book: plays, pamphlets, films, reactions etc./selected and edited by U. Birbaumer. Vienna; Zurich: Europa Verlag, 1989. $415 \mathrm{p}$.

9. Turrini Peter. Death and the devil, a colportage, theater [Tod und Teufel, eine Kolportage, Theater]. Frankfurt am Main: Luchterhand Literaturverlag, $1990.95 \mathrm{p}$.

10. Turrini Peter. Turrini reading book two: pieces, film, poems, reactions etc./selected and edited by U. Birbauer [Turrini Lesebuch zwei: Stücke, Film, Gedichte, Reaktionenetc./ausgewählt und bearbeitet von U. Birbauer]. Vienna; Zurich, 1983. pp. 6-8, 76, 127-129, 206, 402-408.

11. Ryas J. Progress of modern ideas [Postup suchasnykh idei]. Kiev: Fundamentals, 1998. P. 582.

\section{Language features of Peter Turrini's dramaturgy}

\section{M Tkachenko, L. O. Bereza}

Abstract. Some aspects of P. Turrini's work are considered and analyzed. The speech and linguistic features of the reproduction of psychology of representatives of the middle and lower strata of society are characterized. The problems of early and late plays of playwright are covered. It is revealed that with the help of linguistic aspects Peter Turrini developed his original style, characterized first of all by the shock effect that the playwright achieves by his peculiar writing of plays: neglect of spelling norms, use of vulgarisms, jargonand "fecal" expressions, saturation of simple short sentences of heroes by the imperative, which in creased the rudeness of the statements.

Keywords: dialect, dramaturgy, speech aspect, language features, play. 